\title{
Rostrum size differences between Toarcian belemnite battlefields
}

\author{
Patrícia Rita, Kenneth De Baets, and Martina Schlott \\ Geozentrum Nordbayern, Friedrich-Alexander Universität Erlangen-Nürnberg, 91054 Erlangen, Germany
}

Correspondence: Patrícia Rita (patricia.rita@ fau.de)

Received: 20 February 2018 - Revised: 9 May 2018 - Accepted: 14 May 2018 - Published: 7 June 2018

\begin{abstract}
Body size changes have been reported across crisis intervals. Belemnites - now considered extinct stemdecabrachians - have rarely been investigated for this purpose, and the few studies have resulted in ambiguous outcomes. Here we investigate two Toarcian belemnite accumulations in southern Germany from a morphometric point of view with the support of computed tomography data. The aim of this study is to test whether a difference in size can be observed between the rostra of the two studied samples, from individual lineage to community, and which proxy is more reliable. A significant decrease in median size from the Early Toarcian (Dactylioceras tenuicostatum Zone) to the Middle Toarcian (Haugia variabilis Zone) is recognized. This is observed at the community level of organization, considering the whole assemblage, but also within PassaloteuthisAcrocoelites lineage, at the genus level. It is also demonstrated that diameter-based measurements or maximum preserved length are not reliable proxies for size, and therefore apical length or three-dimensional approximations, such as the geometric mean or the post-phragmocone volume, are more advisable. This is especially important when comparing specimens with markedly different rostrum shapes. Further studies are, however, still necessary to disentangle the mechanisms behind the reduction in rostrum size within the Toarcian and their putative environmental causes.
\end{abstract}

\section{Introduction}

The Early Toarcian coincides with a multi-phased crisis (Harries and Little, 1999; Caruthers et al., 2013), which has been mainly attributed to warming and/or anoxia (Little and Benton, 1995; Harries and Little, 1999; Hesselbo et al., 2000; Pálfy and Smith, 2000; Wignall et al., 2005; Danise et al., 2013). This crisis is reflected in biotic communities through the occurrence of two major extinction events and through changes in morphological disparity (Dera et al., 2010, 2016). Among these, body size reductions have been reported in various lineages (Morten and Twitchett, 2009; Martindale and Aberhan, 2017; Rodríguez-Tovar et al., 2017). This socalled Lilliput effect (Harries and Knorr, 2009) has not only been reported for the Toarcian Oceanic Anoxic Event but also for other extinction events (e.g. Twitchett, 2007; Harries and Knorr, 2009; Borths and Ausich, 2010; Rego et al., 2012; Sogot et al., 2014). However, the evolutionary and ecological importance of the Lilliput effect remains poorly understood. Furthermore, because of physiological differences, not all organisms necessarily exhibit a body size reduction in the face of warming or other environmental stresses (Gardner et al., 2011; Ohlberger, 2013). Some authors even consider that, in some cases, the body size reduction might reflect a preservation or collection artefact (McGowan et al., 2009; Brayard et al., 2010).

The Early Toarcian crisis also coincides with a major turnover in belemnite faunas. A drop in diversity, manifested by morphological bottlenecks, is followed by episodes of belemnite diversification during the recovery interval in the Middle-Late Toarcian (Riegraf, 1980; Doyle, 1994; Caswell and Coe, 2014; Ullmann et al., 2014; Dera et al., 2016). A preliminary analysis of the data compiled by Schlegelmilch (1998) on belemnites from southern Germany suggests a decrease in median rostrum size (as a proxy for body size) from the Early to the Middle Toarcian (Fig. 1).

Most of the previous studies on belemnite rostrum size have focused on particular taxa or lineages (Christensen, 2000; Morten and Twitchett, 2009), precluding a proper analysis of the potential differences observed when considering rostrum size changes at different levels of organization (i.e. populations, communities, individuals). In addition, the methods applied usually focus on the analysis of a single morphometric parameter, such as maximum diameter. Despite the fact that the rostrum diameter is often exposed and 


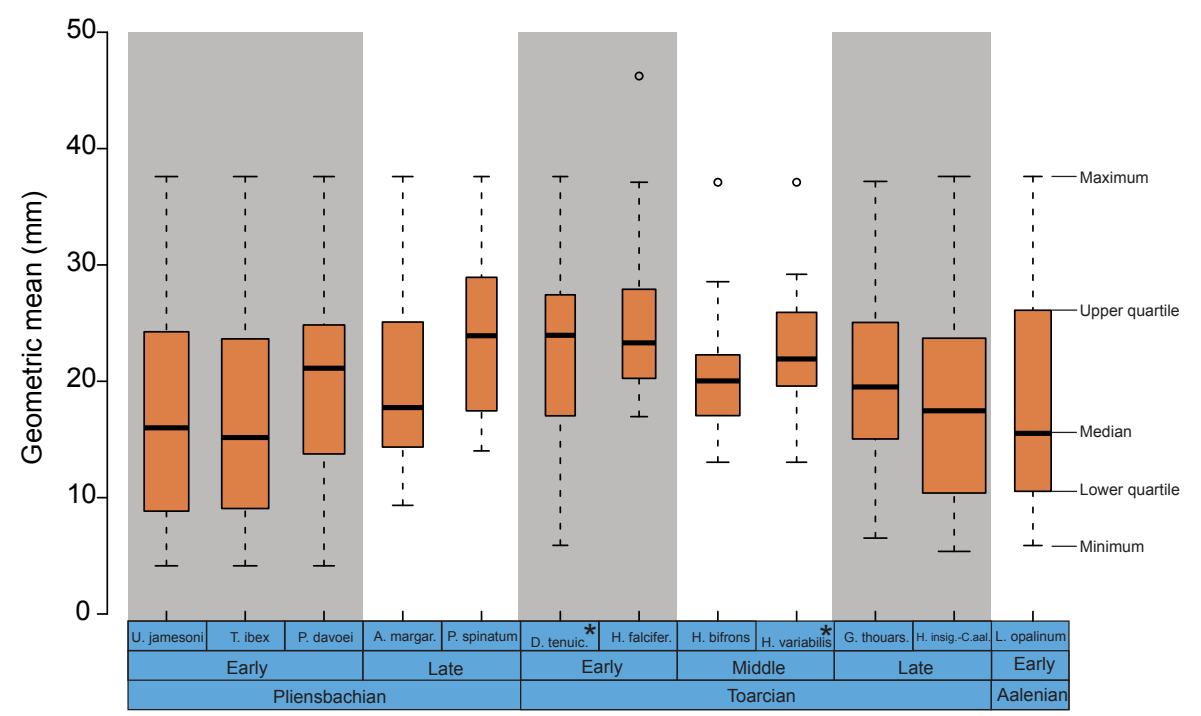

Figure 1. Belemnite body size fluctuations across the Pliensbachian (Uptonia jamesoni Zone)-Aalenian (Leioceras opalinum Zone) interval, according to Schlegelmilch (1998). A body size reduction is observed from the Early to the Middle Toarcian. Timescale according to Dera et al. (2016). The width of the boxes is proportional to the number of observations. Asterisks indicate the sampled levels.

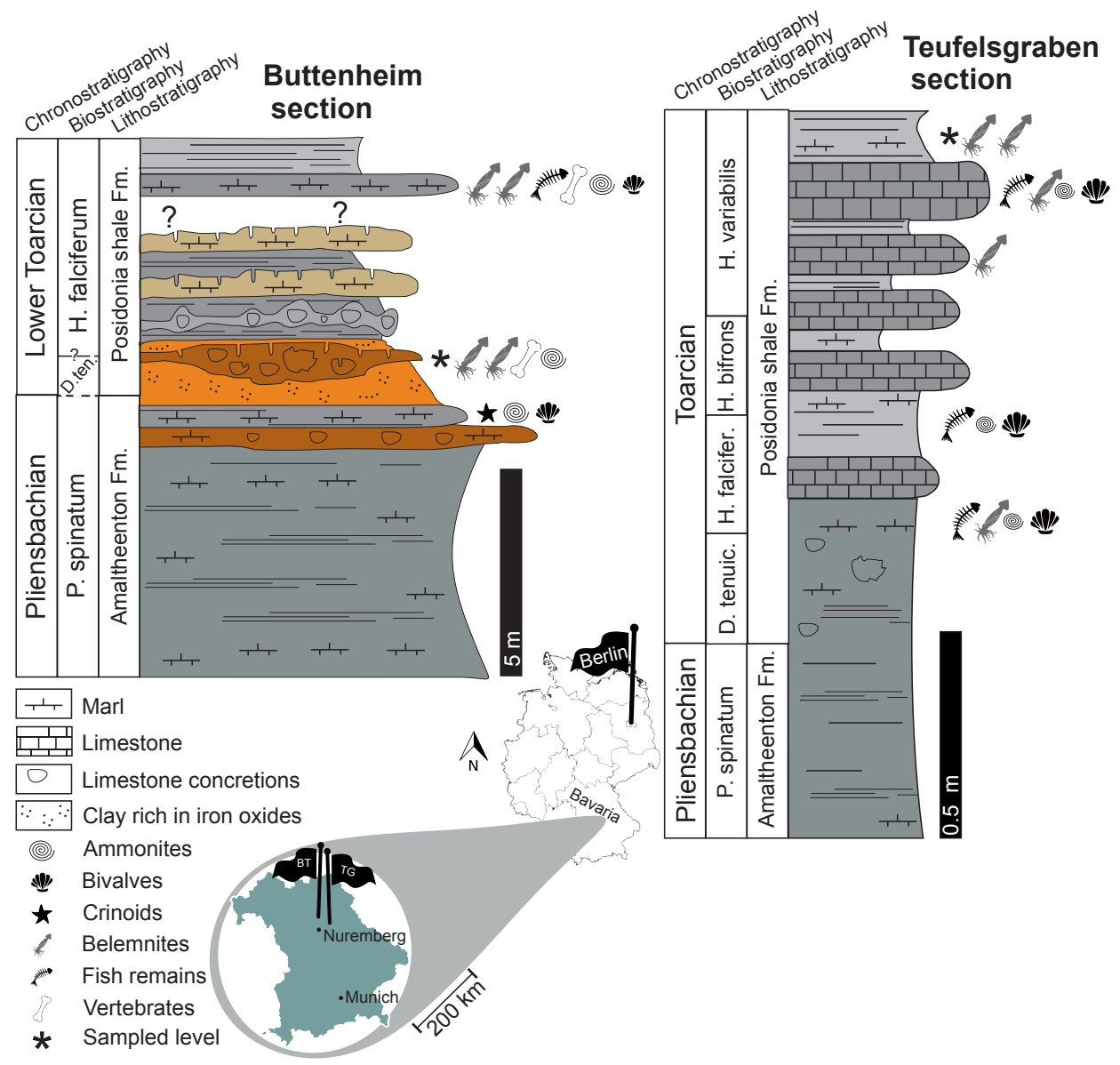

Figure 2. Location of the studied sections in Bavaria, southern Germany, and sampled stratigraphic levels: Buttenheim (BT) $\left(49^{\circ} 47^{\prime} 41.83^{\prime \prime} \mathrm{N}\right.$, $\left.11^{\circ} 2^{\prime} 42.47^{\prime \prime} \mathrm{E}\right)$ and Teufelsgraben (TG) $\left(49^{\circ} 35^{\prime} 41.40^{\prime \prime} \mathrm{N}, 11^{\circ} 16^{\prime} 20.90^{\prime \prime} \mathrm{E}\right)$. 


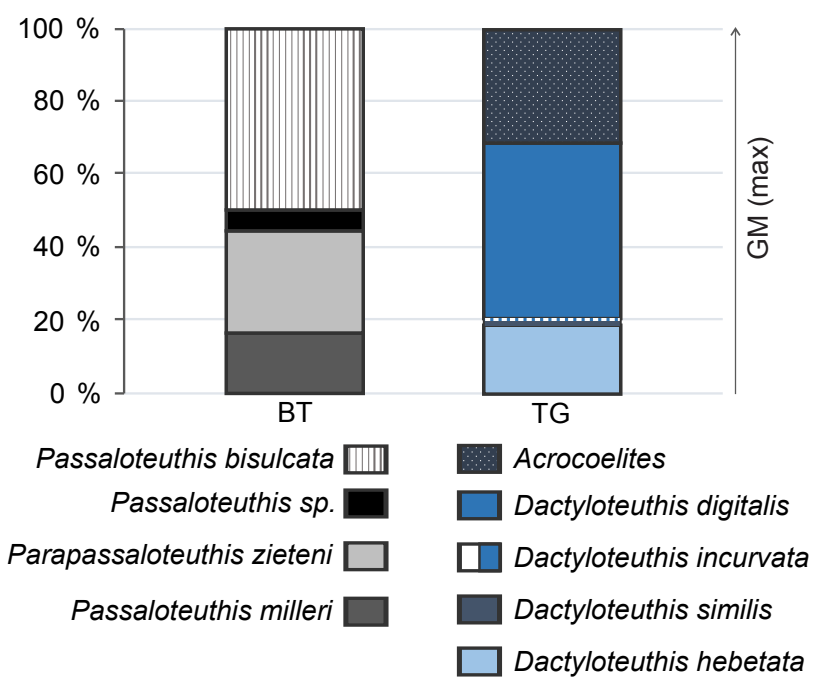

Figure 3. Proportion of the main taxa identified in Buttenheim (BT) and Teufelsgraben (TG) sections, organized vertically according to relative rostrum size (maximum geometric mean). Acrocoelites includes A. quenstedi, A. pyramidalis and A. subbrevis and A. sp., which were merged in order to reach a comparable sample size, regarding the remaining taxa.

easily measurable, it can be misinterpreted in partially embedded or broken specimens. In addition, it has been demonstrated that the error on the diameter-based measurements is comparatively larger than the error associated with lengthbased measurements. This is related to preservation issues as well as the smaller dimension of the diameter in comparison with length (De Baets et al., 2013). The rostrum length would also be more closely correlated with the mantle length used in extant coleoid size studies (Roper and Voss, 1983), but the alveolar region is often flattened and/or broken, hampering precise measurements. Unidimensional or linear shell measurements, particularly diameter, are potentially imprecise when comparing morphologically dissimilar taxa. Therefore, the apical length or volumetric estimates (Novack-Gottshall, 2008) as well as the geometric mean of two or three dimensions (Jablonski, 1996; Dommergues et al., 2002; Kosnik et al., 2006; Nürnberg et al., 2012) might be more appropriate for size studies, the latter particularly when comparing specimens with markedly different rostrum morphologies. To achieve this, we focus here on the post-alveolar part of the orthorostrum (rostrum solidum), since the belemnite posterior soft tissues closely track its outline (e.g. in Mesozoic coleoids, the fins typically attach to it: Fuchs et al., 2015) and it partially counterbalances the belemnite phragmocone and soft parts (Monks et al., 1996). The contribution of the rostrum on buoyancy would depend on its structure and porosity (see Discussion).

Due to their exceptionally high abundance in belemnite rostra, belemnite battlefields are ideal to obtain large samples for a rostrum size analysis, although various mechanisms can contribute to the formation of belemnite accumulations (Urlichs, 1971; Doyle and Macdonald, 1993). In many cases, a certain degree of condensation might be involved, resulting in temporal and/or spatial averaging. However, this is probably equivalent to the result of merging several layers of less rich accumulations in order to reach an appropriate sample size. Therefore, further analysis is necessary to investigate whether battlefields can be considered a useful resource for rostrum size analysis.

Here we compare data from two distinct belemnite battlefields in order to examine whether a rostrum size difference can be recognized between them, as is indicated by the analysis of the latest comprehensive literature survey from the considered interval (Schlegelmilch, 1998). The main aim is to assess the performance of individual traditional morphometric parameters or a combination of these as volume metrics or as proxies for rostrum size, considering either the entire assemblage of belemnites (community level of organization) or particular lineages (genus level of organization).

\section{Material and methods}

\subsection{Material}

We focused our study on two Toarcian belemnite battlefields (Doyle and Macdonald, 1993) from Franconia, southern Germany, in the Buttenheim and Teufelsgraben localities (Fig. 2). We sampled all belemnite rostra from predetermined well-accessible areas within the two considered belemnite battlefields. The well-preserved specimens (i.e. at least with the rostrum solidum preserved) were determined to the species level and measured (Table S2 in the Supplement; Fig. 3). No epirostrum-bearing specimens were recorded in the studied sites. Due to the absence of common species in the datasets, an individual lineage, the Passaloteuthis-Acrocoelites line (e.g. Schlegelmilch, 1998), was selected, since it includes two genera with very similar features which comprise an important proportion of the assemblages (Fig. 4). Therefore, this group includes all the specimens belonging to Passaloteuthis and Acrocoelites genera.

From Buttenheim, 72 specimens were collected from a clay-rich sediment at the top of the Bollernbank (see Fig. 1). Despite the presence of Upper Pliensbachian reworked fossils, the Bollernbank in Buttenheim is thought to represent the most basal Toarcian (Hoffmann et al., 2007; Keupp and Schweigert, 2008), especially if we consider the belemnites deriving from claystones, which are autochthonous, according to Bandel and Knitter (1983).

The belemnite battlefield in Teufelsgraben, which can be traced from Möning, near Neumarkt, to Unterstürmig, north of Forchheim, is usually attributed to the Upper Toarcian Grammoceras thouarsense Zone (Urlichs, 1971). How- 

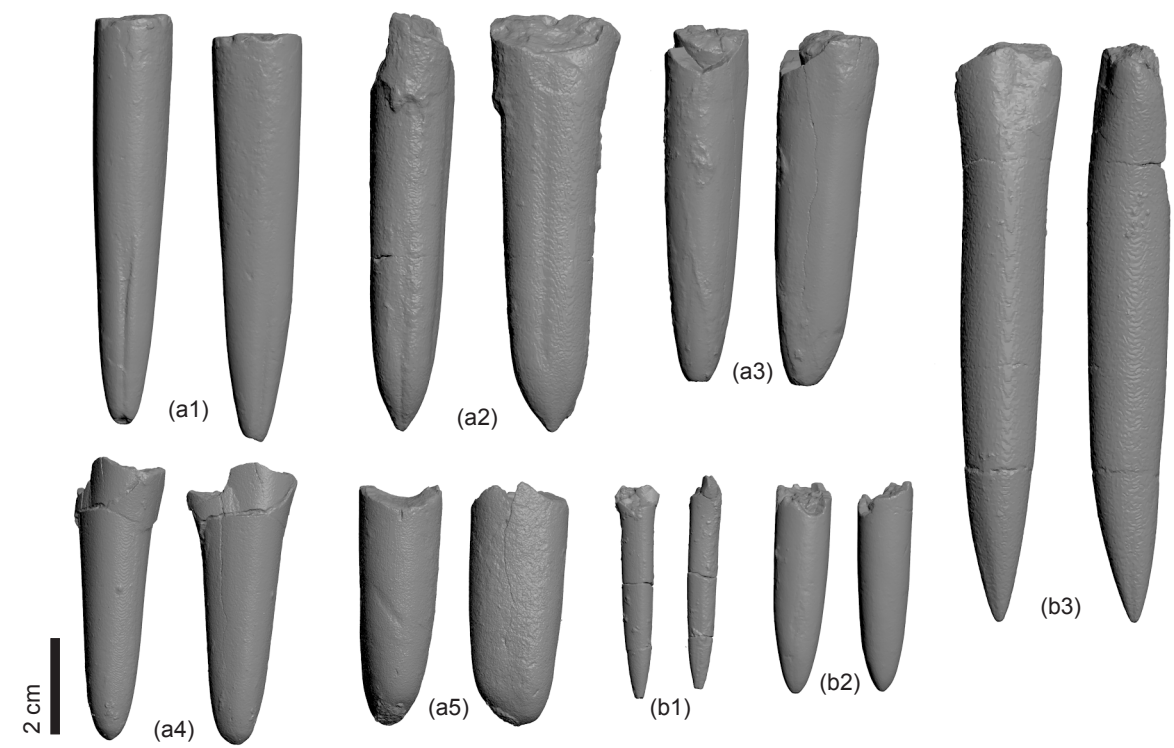

Figure 4. Belemnite rostra from Teufelsgraben (a) and Buttenheim (b): a1 - Acrocoelites quenstedi; a 2 - Dactyloteuthis incurvata; a3 Dactyloteuthis similis; a4 - Dactyloteuthis hebetata; a5 - Dactyloteuthis digitalis; b1 - Passaloteuthis milleri (juvenile); b2 - Parapassaloteuthis zieteni; b3 - Passaloteuthis bisulcata. Left corresponds to ventral (a) or dorsal (b) view and right corresponds to lateral view. For more taxa see Figs. S1, S2 and S3 in the Supplement.

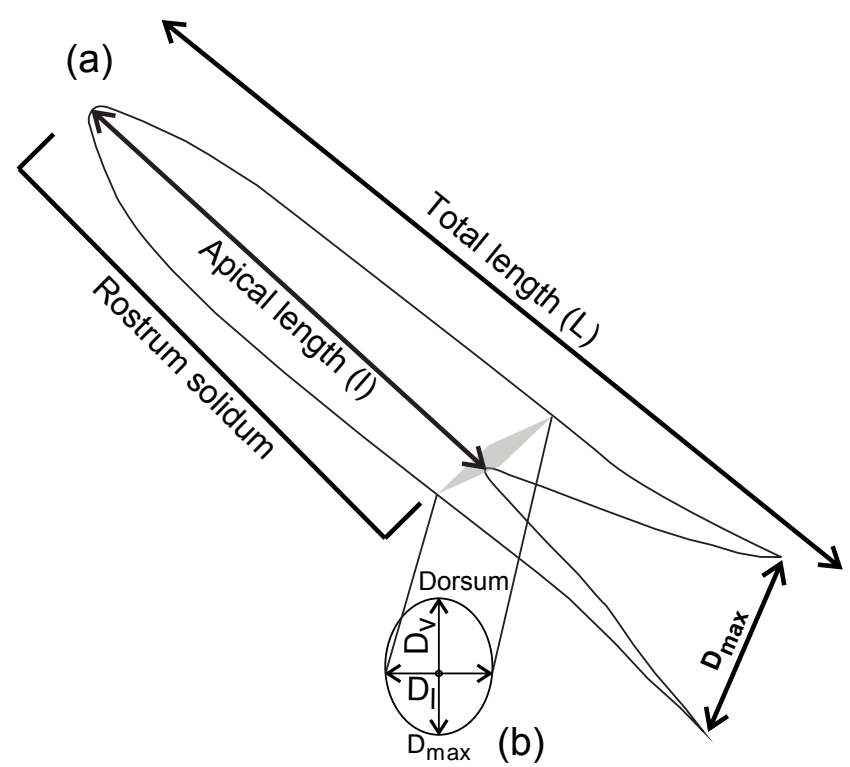

Figure 5. Longitudinal view (a) and transverse section (b) of belemnite rostrum with the measured parameters indicated: total length, apical length, height $\left(D_{\mathrm{v}}\right)$, width $\left(D_{1}\right)$, and maximum diameter $\left(D_{\max }\right)$.

ever, recent chemostratigraphy data on Teufelsgraben material suggests an attribution to the Haugia variabilis Zone (Middle Toarcian; Kallina, 2016). A total of 111 belemnite rostra were collected in this section.
According to the accumulation scheme of Doyle and Macdonald (1993), the Buttenheim and Teufelsgraben battlefields belong to the stratigraphical type of accumulation, as condensation played a role in both cases (Urlichs, 1971; Bandel and Knitter, 1983). In Teufelsgraben, there is also clear evidence for current alignment (Urlichs, 1971), which could not be documented in the Buttenheim section. Both accumulations include specimens with evidence of epifaunal colonization by boring organisms (e.g. barnacles: Seilacher, 1968). We therefore consider the Buttenheim battlefield to be an ancient lag subtype, rather than the transported concentration subtype of Doyle and Macdonald (1993).

\subsection{Morphometry}

Because belemnite soft tissues are rarely preserved (Reitner and Urlichs, 1983; Klug et al., 2010; Clements et al., 2017), their rostrum is used as a proxy for their body size. We measured the rostrum parameters traditionally reported in the literature (Doyle, 1990; Schlegelmilch, 1998; Sanders et al., 2015): total length $(L)$, apical length ( $l$, i.e. postphragmocone length measured from apex to protoconch), height $\left(D_{\mathrm{v}}\right)$ and width $\left(D_{1}\right)$ at the protoconch level, adopting the abbreviations used by Doyle (1990) (Fig. 5). We approximated the measurement of the maximum diameter $\left(D_{\max }\right.$; as it is in the bedding plane) by using the largest measured diameter (typically at the aperture for our specimens, which are of conical and cylindrical shape), as it was also previously used in size analyses (Morten and Twitchett, 2009) (Fig. 5). After considering each of these parameters individually, a 
three-dimensional approach was implemented by calculating the geometric mean (GM; Eq. 1) and using different volume formulas, such as elliptical cylinder ( $V_{\text {ecy }}$; Eq. 2), elliptical cone ( $V_{\text {ec }}$; Eq. 3 ), and their arithmetic mean ( $V_{\text {med }}$; Eq. 4$)$. This derived volume was further compared with empirical data, i.e. volume directly calculated from the micro-CT scans (post-phragmocone volume and total volume).

$$
\begin{aligned}
& \mathrm{GM}=\sqrt[3]{D_{1} \times D_{\mathrm{v}} \times l} \\
& V_{\mathrm{ecy}}=\pi \times l \times \frac{D_{\mathrm{v}}}{2} \times \frac{D_{\mathrm{l}}}{2} \\
& V_{\mathrm{ec}}=\frac{1}{6} \times \pi \times l \times D_{\mathrm{v}} \times D_{\mathrm{l}} \\
& V_{\text {med }}=V_{\left(V_{\mathrm{ecy}}+V_{\mathrm{ec}}\right) / 2}=\frac{4}{3} \pi \times D_{\mathrm{v}} \times D_{\mathrm{l}} \times l
\end{aligned}
$$

\subsection{Computed tomography}

In order to obtain the measurements at the position of the protoconch without destroying the specimens and to have a direct way of measuring the volume, all the well-preserved specimens (i.e. with at least the rostrum solidum preserved) were scanned with our in-house micro-CT phoenix $v \mid$ tome $\mid x s 240$ (Research Edition) scanner. For this purpose, 117 specimens (78 from Teufelsgraben and 39 from Buttenheim) were mounted in a florist foam block for stability. This material has very low X-ray attenuation and thus is readily distinguishable from the specimen. An average of 884 projections with a $0.5 \mathrm{~mm}$ copper filter were obtained at approximately $174 \mathrm{kV}$ and $320 \mathrm{~mA}$, in accordance with the size of the specimens. Settings were chosen on a sample-specific basis based on an optimal compromise between spatial resolution, contrast resolution, and scan acquisition time (Table $\mathrm{S} 1$ ). The reconstruction was made with the GEDatos $\mid x 2.4$ software. Subsequent image stack processing (e.g. subsampling), as well as the measurements and volume acquisition, was derived using Studio Volume Graphics $\operatorname{Max}^{\mathrm{TM}}$ v 3.0 software (Heidelberg). Some additional specimens were measured using a calliper (Table S2, specimens lacking volume data information). Both postphragmocone volume (PPV; i.e. the volume of the rostrum solidum) and total volume (TV) were calculated. Additional information about the scans and the specimens measured can be found in the Supplement (Tables S1 and S2). The renderings (Figs. 4, S1 and S2) were made with the open-source software Blender 2.78.

\subsection{Taxonomy and ontogeny}

Belemnites were cleaned in order to enhance the visibility of features that allow a proper determination at species level, based on published descriptions and figures (Riegraf et al., 1984; Doyle, 1990, 1992; Schlegelmilch 1998; Pinard et al., 2014; Sanders et al., 2015; Weis et al., 2018). Species identification was based on analysis of traditional features, such as shape (outline and profile) and the presence of grooves

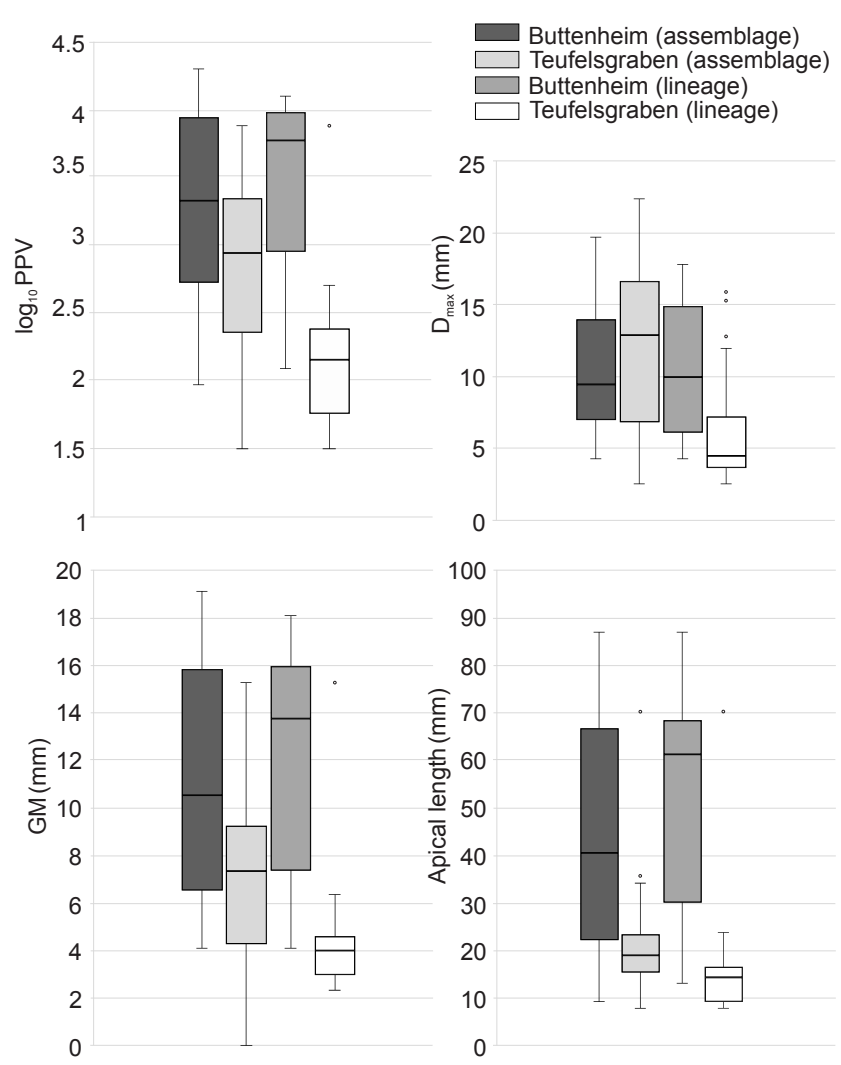

Figure 6. Box and whisker plots for the whole belemnite assemblage and the Passaloteuthis-Acrocoelites lineage for the Teufelsgraben and Buttenheim sections representing the distribution of some of the different measured ( $l$ and $D_{\max }$ ) and calculated (GM, PPV) morphometric parameters.

in the apical region (ventral or dorso-lateral) (Figs. 4, S1, S2 and S3). The transverse section, depth of penetration of the alveolus, and the apical line were observed using the CTscanning method. This method also allowed us to recognize the features of each ontogenetic stage with the acquired longitudinal sections. Features such as shape, grooves (using the transverse sections), depth of penetration of the alveolus, and the apical line were observed and compared with literature descriptions (Doyle, 1990, 1992), allowing us to distinguish between adult (ephebic-gerontic sensu Doyle, 1990) and juvenile (nepionic-neanic sensu Doyle, 1990) specimens.

\subsection{Statistics}

In our analyses of the two battlefields, the medians of the different morphometric parameters were compared using nonparametric tests, namely the Mann-Whitney $U$ test (Mann and Whitney, 1947) and Mood's median test (Mood, 1941, 1954), both at community (whole assemblage) and population (Passaloteuthis-Acrocoelites lineage) levels. The distribution of rostrum size measurements was compared using the non-parametric Kolmogorov-Smirnov test (Kolmogorov, 


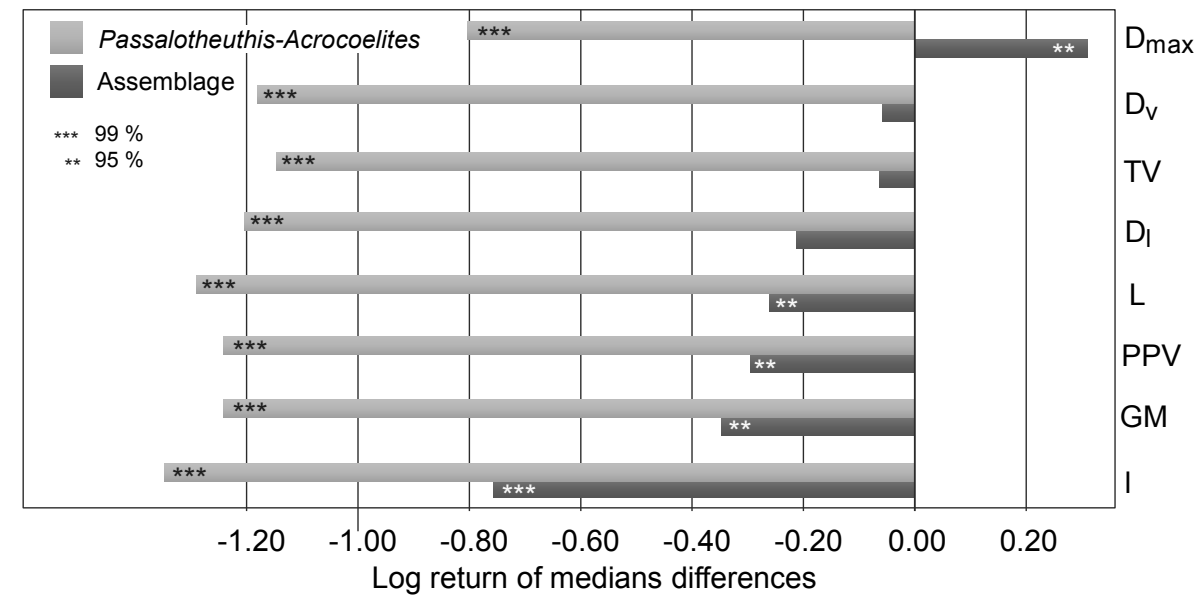

Figure 7. Log return of median differences for different measured $\left(l, L, D_{\mathrm{v}}, D_{1}\right.$ and $\left.D_{\max }\right)$ and calculated (GM, PPV, TV) morphometric parameters for both the whole belemnite assemblage and the Passaloteuthis-Acrocoelites lineage, for the Buttenheim and Teufelsgraben sections. Asterisks refer to the confidence levels and their absence indicate non-significant $p$ values for at least one of the tests performed (see Table 1). Except for $D_{\max }$, all parameters indicate that the median rostrum size in the Teufelsgraben assemblage is smaller than in the Buttenheim assemblage.

Table 1. $p$ values for differences in distribution (Kolmogorov-Smirnov test) and median (Mann-Whitney and Mood's median tests) of the Teufelsgraben and Buttenheim assemblages. The results are given for the whole belemnite assemblage and for the Passaloteuthis-Acrocoelites lineage. Non-significant values are marked in bold.

\begin{tabular}{|c|c|c|c|c|c|c|c|c|}
\hline & \multicolumn{2}{|c|}{$\begin{array}{c}\text { Dactylioceras } \\
\text { tenuicostatum Zone- } \\
\text { Haugia variabilis } \\
\text { Zone (Schlegelmilch, 1998) }\end{array}$} & \multicolumn{3}{|c|}{ Assemblage } & \multicolumn{3}{|c|}{ Passaloteuthis-Acrocoelites lineage } \\
\hline & $\begin{array}{r}\text { Mann- } \\
\text { Whitney test }\end{array}$ & $\begin{array}{l}\mathrm{K}-\mathrm{S} \\
\text { test }\end{array}$ & $\begin{array}{r}\text { Mann- } \\
\text { Whitney test }\end{array}$ & $\begin{array}{r}\text { Mood's } \\
\text { median test }\end{array}$ & $\begin{array}{r}\mathrm{K}-\mathrm{S} \\
\text { test }\end{array}$ & $\begin{array}{r}\text { Mann- } \\
\text { Whitney test }\end{array}$ & $\begin{array}{r}\text { Mood's } \\
\text { median test }\end{array}$ & $\begin{array}{l}\mathrm{K}-\mathrm{S} \\
\text { test }\end{array}$ \\
\hline$L$ & 0.692 & 0.823 & $1.33 \mathrm{E}-04$ & $1.89 \mathrm{E}-02$ & $1.34 \mathrm{E}-04$ & $9.79 \mathrm{E}-10$ & $9.43 \mathrm{E}-11$ & $2.94 \mathrm{E}-10$ \\
\hline$l$ & 0.280 & 0.029 & $2.41 \mathrm{E}-08$ & $1.30 \mathrm{E}-07$ & 5.27E-08 & $6.92 \mathrm{E}-09$ & $2.35 \mathrm{E}-10$ & $1.46 \mathrm{E}-10$ \\
\hline$D_{\mathrm{v}}$ & 0.231 & 0.145 & 1.72E-01 & 8.00E-01 & 6.03E-02 & 3.59E-09 & $6.30 \mathrm{E}-09$ & $1.11 \mathrm{E}-09$ \\
\hline$D_{1}$ & 0.831 & 0.513 & $9.42 \mathrm{E}-04$ & 3.18E-01 & 2.37E-03 & 2.69E-09 & $6.30 \mathrm{E}-09$ & $2.31 \mathrm{E}-09$ \\
\hline GM & 0.859 & 0.669 & $6.44 \mathrm{E}-05$ & 2.37E-02 & $6.04 \mathrm{E}-05$ & 2.23E-09 & $2.35 \mathrm{E}-10$ & $2.15 \mathrm{E}-10$ \\
\hline$D_{\max }$ & - & - & $1.95 \mathrm{E}-02$ & $5.15 \mathrm{E}-04$ & $2.41 \mathrm{E}-03$ & 4.60E-07 & 8.62E-05 & $3.54 \mathrm{E}-06$ \\
\hline TV & - & - & $9.04 \mathrm{E}-03$ & 2.96E-01 & $1.69 \mathrm{E}-02$ & $1.33 \mathrm{E}-08$ & 2.91E-08 & 3.37E-09 \\
\hline PPV & - & - & 4.71E-04 & $3.90 \mathrm{E}-02$ & $8.88 \mathrm{E}-05$ & 3.94E-09 & $2.35 \mathrm{E}-10$ & $7.62 \mathrm{E}-10$ \\
\hline
\end{tabular}

1933; Smirnov, 1948). The tests were implemented using R, version 3.4.4 (R Core Team, 2018). The magnitude of change from one interval to the next was assessed through the natural logarithmic return (Hudson and Gregoriou, 2015), the log ratio of the median of rostrum size estimates (example: $\frac{\text { (median of } D_{\mathrm{V}} \text { from Teugelsgraben) }}{\text { (median of } D_{\mathrm{v}} \text { from Buttenheim) }}$ ). This metric is independent of absolute rostrum size and symmetrical for both losses and gains. In order to make PPV and TV comparable with the rest of the rostrum size proxies, the third root of these two volumes was used in the $\log$ ratio.

\section{Results}

When considering the whole belemnite assemblage, the two battlefields have significantly different distributions, according to the Kolmogorov-Smirnov test (Fig. 6 and Table 1). This can be observed when taking into account either the individual morphometric parameters $\left(L, l, D_{\mathrm{v}}, D_{1}\right.$ and $\left.D_{\max }\right)$ or the three-dimensional parameters (GM, TV and PPV), with at least a $90 \%$ confidence level (Table 1). The least significant parameters are TV and $D_{\mathrm{v}}$ (Table 1). For the Passaloteuthis-Acrocoelites lineage, all the considered morphometric parameters are significantly different, with a $99 \%$ confidence level (Table 1), revealing a smaller rostrum size 


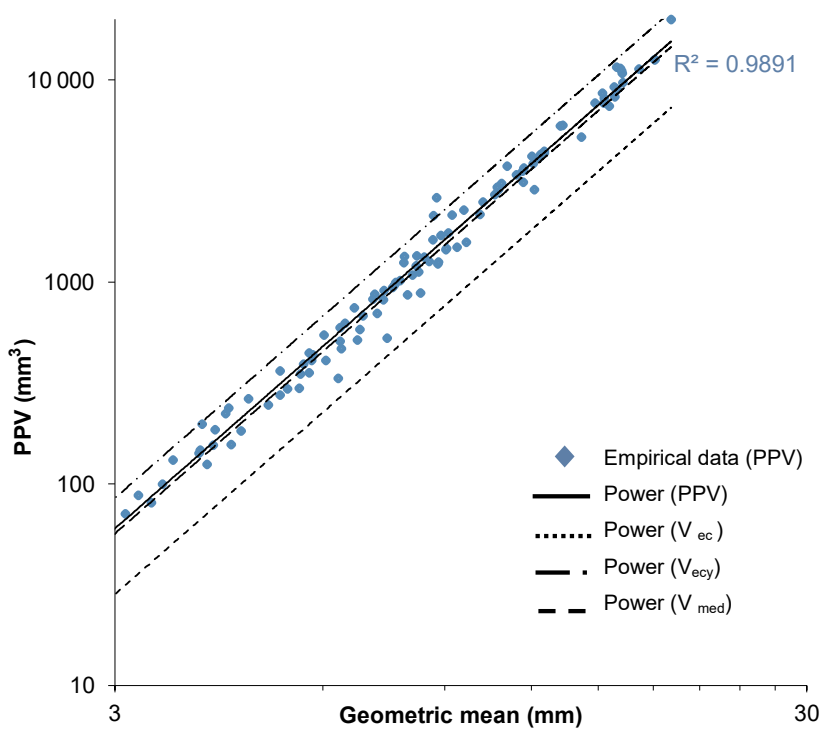

Figure 8. Comparison of empirical volume data (PPV) with power relationships fitted to estimated volumes based on different formulas $\left(V_{\mathrm{ecy}}, V_{\mathrm{ec}}, V_{\mathrm{med}}\right)$ by using empirical linear dimensions. 0.9891 corresponds to the $R^{2}$ value of the empirical data trend line (continuous black line).

in the Teufelsgraben belemnite battlefield than in Buttenheim (Fig. 6).

For the whole belemnite assemblage, all the different rostrum size parameters, except for Dmax, indicate that the median rostrum size in Buttenheim is larger than in Teufelsgraben. The largest decrease observed in median size between the two assemblages is indicated by $l$ followed by GM, PPV, $L, D_{\mathrm{l}}$, and TV $/ D_{\mathrm{v}}$ (Fig. 7). With the exception of $D_{\mathrm{v}}$, $\mathrm{TV}$, and $D_{1}$, all parameters are significantly different for a $95 \%$ confidence level (Table 1). The magnitude of difference shown by the empirical volume measurements (PPV) is equivalent to the changes observed in $L$ and GM, and they are significant for a $95 \%$ confidence level. The length $l$ seems to provide less conservative values of the magnitude of difference between the two datasets considered, in comparison with the empirical data. The exception to the trend observed is Dmax, reporting a rostrum size increase from Buttenheim to Teufelsgraben, with a $95 \%$ confidence level (Fig. 7).

Within the Passaloteuthis-Acrocoelites lineage, the largest differences in median are observed in $l$ followed by $L$, PPV and GM, $D_{1}, D_{\mathrm{v}}, \mathrm{TV}$, and Dmax (Fig. 7). Mood's median and the Mann-Whitney tests indicate a statistically significant difference between the two datasets, with a $99 \%$ confidence level (Table 1). The majority of the parameters considered reproduce the results given by the empirical data in terms of the median magnitude of change. However, Dmax provides an underestimation, showing a smaller magnitude of difference in the medians (Fig. 7).

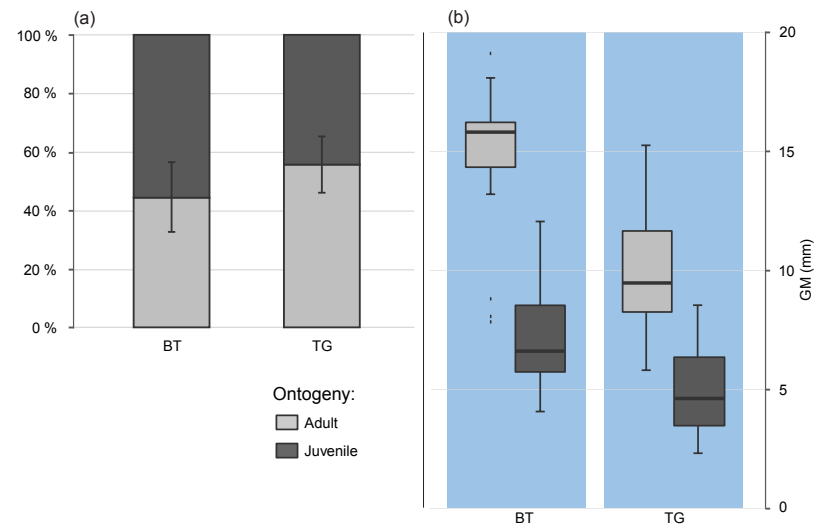

Figure 9. Proportion of ontogenetic stages (a) and rostrum size variation (geometric mean) of adults and juveniles (b) from Buttenheim (BT) and Teufelsgraben (TG) belemnite battlefields. Both adults and juveniles from Teufelsgraben reveal lower rostrum size when compared to equivalent ontogenetic stages from the Buttenheim assemblage. The differences in median and in distribution for both adults (K-S test, $p$ value $=1.53 \times 10^{-10}$; Mann-Whitney test, $p$ value $=4.66 \times 10^{-8}$ ) and juveniles are significant $\left(\mathrm{K}-\mathrm{S}\right.$ test, $p$ value $=2.68 \times 10^{-3}$; Mann-Whitney test, $p$ value $\left.=1.81 \times 10^{-4}\right)$.

The empirical estimates of the post-phragmocone rostrum volume (PPV) obtained from the scans were compared with volume values calculated using different formulas $\left(V_{\mathrm{ecy}}, V_{\mathrm{ec}}\right.$, $V_{\text {med }}$ ). We observed that PPV is typically smaller than $V_{\text {ecy }}$ and larger than $V_{\mathrm{ec}}$. The volumes $V_{\mathrm{ecy}}$ and $V_{\mathrm{ec}}$ were calculated using $D_{\mathrm{v}}, D_{1}$, and $l$. In fact, PPV is almost indistinguishable from $V_{\text {med }}$ (Fig. 8).

Both assemblages are comprised of adult and juvenile specimens. The assemblage from Buttenheim contains $44.4 \%$ of adult specimens and $55.6 \%$ of juveniles (Fig. 9a). The proportion of adults in Teufelsgraben is slightly higher $(55.9 \%)$, and juvenile specimens represent $44.1 \%$ of the assemblage. The variation in rostrum size within ontogeny was assessed by comparing the differences in the GM between assemblages (Fig. 9b). Both adults and juveniles from Teufelsgraben reveal lower median rostrum size when compared to equivalent ontogenetic stages from the Buttenheim assemblage at the community level. The differences in the median among adults are larger than among juveniles (Fig. 9b). However, for the adults of the Passaloteuthis-Acrocoelites lineage, the differences between samples are not significant. The only adult specimen belonging to Acrocoelites from Teufelsgraben $(\mathrm{GM}=15.25 \mathrm{~mm})$ falls within the $95 \%$ confidence interval of the adult Passaloteuthis from Buttenheim. 


\section{Discussion}

\subsection{The best proxy for rostrum size}

By comparing the rostrum size of two different belemnite battlefields, we demonstrate that, for the entire assemblage, the size changes indicated by empirical volumetric data are equivalent to the results given by the geometric mean, which takes into account post-phragmocone measurements (Fig. 7). Length-based measurements ( $L$ and $l$ ), when used individually, might slightly overestimate the differences between the two samples, if markedly different shapes of rostra are involved. However, they perform better than diameter-based metrics, which are demonstrated to provide weaker (less significant) or even opposite rostrum size patterns, when studying an entire assemblage. For the maximum diameter, we even obtained a statistically significant rostrum size increase from Buttenheim to Teufelsgraben, while all the other parameters indicated the opposite trend (Fig. 7).

When considering a particular lineage, in this case the Passaloteuthis-Acrocoelites lineage, the geometric mean can also be used as a proxy for rostrum size, providing precisely the same magnitude of difference between the medians as well as the total length (Fig. 7). However, if we consider the apical length individually, it slightly exaggerates the differences observed between the two samples. In contrast with the results of the whole assemblage, width measurements seem to perform only slightly worse than the geometric mean, when considering this lineage (Fig. 7). However, the maximum diameter underestimates the differences that exist between the two samples (Fig. 7).

The total volume is less reliable than the postphragmocone volume, revealing an underestimated magnitude of difference between the medians of the two populations, in the case of the Passaloteuthis-Acrocoelites lineage (Fig. 7). For the whole assemblage, the total volume did not reveal significant rostrum size differences between the two samples, according to the results of Mood's median test (Table 1). The reason for this might be the fragility of the alveolar region, included in the total volume, which is often flattened and/or incomplete. For the same reason, the total length should not be used on its own as a proxy for belemnite rostrum size in poorly preserved specimens. However, if the preservation is good, by analogy with the mantle length measured in extant cephalopods (Nixon and Young, 2003; Hoving et al., 2013), the total length is probably a more accurate proxy for belemnite rostrum size.

For the reasons mentioned above, post-phragmocone measurements are more desirable for belemnite rostrum size analyses, especially if we can combine them in a threedimensional approach, such as the geometric mean or empirical volume estimate. The only disadvantage of the usage of these metrics on size studies is the difficulty of measuring the morphometric parameters without CT scanning or destructive polished sections. CT scanning might be preferred, as specimens do not necessarily have to be destroyed, and has the advantage that the entire volume, in addition to the postalveolar length, can be easily estimated. Furthermore, when additional destructive methods are necessary (e.g. geochemistry), CT scans can be a useful tool, as they are a valuable way of digitally storing all the morphological information of the specimens.

The rostrum represents a considerable part of the belemnite animal, and it is hypothesized that it acts as a counterbalance for the soft parts and phragmocone (Monks et al., 1996). Despite the increasing amount of studies suggesting an original porous rostrum structure (or at least less calcified) (Spaeth, 1975; Benito et al., 2016; Hoffmann et al., 2016), in most belemnites, the rear soft parts closely track the rostrum outline. In addition, the rostrum is thought to be the attachment of the fins in belemnoids in general (Reitner and Urlichs, 1983; Klug et al., 2016). For these reasons, the rostrum can be considered a reasonable proxy for body size in the absence of preserved soft parts. However, if epirostrumbearing specimens are part of the assemblage, the usage of this structure might compromise the size analysis. The epirostrum is thought to develop late in ontogeny (Arkhipkin et al., 2015), probably as a quite porous (or largely hollow) structure (Bandel and Spaeth, 1988; Stevens et al., 2017). This apparent body length increase of the animal was probably not related to a proportional increase in soft-tissue volume (as would be the case for a more massive rostrum). Therefore, it is not advisable to directly compare epirostrumbearing specimens with specimens which did not develop such structures. However, no epirostrum-bearing specimens were recorded in our study.

Regardless of the possible relationship between rostrum size and belemnite soft body size, rostrum volume or its geometric mean is a more conservative proxy for belemnite body size than diameter-based measurements or rostrum total (preserved or maximum) length. However, further testing, particularly when comparing forms with markedly different rostrum shapes, might be necessary.

\subsection{A belemnite size decrease during the Toarcian?}

The combined analysis of different rostrum size proxies and empirical volume data revealed a significantly smaller size of the specimens from the Middle Toarcian (Haugia variabilis Zone, Teufelsgraben) than those from the Early Toarcian (Dactylioceras tenuicostatum Zone, Buttenheim), at the community level of organization (i.e. entire belemnite assemblage) (Fig. 6). The analysis of the published data on the biozone level in southern Germany by Schlegelmilch (1998) reveals the same pattern (Fig. 1), although the differences between the two biozones are not significant (Table 1). Interestingly, when studying the particular lineage PassaloteuthisAcrocoelites, the same trend is observed (Fig. 7). The Schlegelmilch (1998) dataset represents the latest comprehensive synthesis of belemnite literature; however, the mea- 
surements presented should be reviewed with caution, since the stratigraphic provenance of specimens is not always precisely known. In addition, they are taken from various publications, compromising their suitability for comparison with natural assemblages.

Depending on the physiological mechanisms involved and the possible causes, a body size decrease could be recognized at different biological scales of organization (Daufresne et al., 2009; Ohlberger, 2013). Therefore, a body size decrease at the community level can reflect changes in the taxonomic composition of the assemblages at the population level (i.e. the disappearance of large-sized taxa at the population level) or an increase in the proportion of juveniles at the genus level. In the studied case, however, we can rule out the effect of the ontogenetic proportion as the cause of the reduced rostrum size recognized at the community level, since the Teufelsgraben assemblage reveals a lower proportion of juveniles (Fig. 9a). Furthermore, the rostrum size reduction is recognized in both adult and juvenile stages (Fig. 9b).

Apart from the Passaloteuthis-Acrocoelites lineage, which is present in both samples, the Buttenheim assemblage also includes Parapassaloteuthis zieteni, the smallest taxa of the two assemblages, which is not represented in Teufelsgraben. Dactyloteuthis is exclusively represented in the Teufelsgraben assemblage and it comprises more than $60 \%$ of the assemblage. This genus includes relatively large (Dactyloteuthis digitalis) to relatively small taxa (Dactyloteuthis hebetata) (Fig. 3). At the community level of organization, the replacement of Parapassaloteuthis zieteni by Dactyloteuthis, with a larger median GM, would potentially counteract the trend seen in the Passaloteuthis-Acrocoelites lineage. However, at the community level, a significant decrease can still be recognized in GM between both assemblages - albeit smaller and less significant than the decrease observed in the PassaloteuthisAcrocoelites lineage $\left(p\right.$ value assemblage $=6.44 \times 10^{-5}$; $p$ value $_{\text {lineage }}=1.893 \times 10^{-12}$ ) (Fig. 6). For this reason, we conclude that the disappearance of Parapassaloteuthis zieteni and the appearance of Dactyloteuthis (i.e. changes in the taxonomic composition) play a smaller role in the community rostrum size differences than the rostrum size changes within the Passaloteuthis-Acrocoelites lineage.

Current alignment has been reported for the battlefield of Teufelsgraben (Urlichs, 1971). However, it is very unlikely that current transport on its own could entirely explain the differences in rostrum size distribution between the two datasets, as it is expected that smaller specimens would be more prone to destruction and winnowing by currents than larger specimens, which would rather drive the pattern in the opposite direction. Furthermore, the specimens might have been exposed to similar taphonomic filters in Buttenheim (Bandel and Knitter, 1983). Nevertheless, the mechanisms of formation of battlefields (e.g. effects of currents, condensation, and reworking) need to be further investigated, due to the influence that they revealed to have on cephalopod size distribution (e.g. flatter distribution in cases of higher condensation or winnowing, or relative destruction of smaller specimens by currents; Mancini, 1978; De Baets et al., 2015).

In extant relatives of belemnites, which are now considered to be stem-decabrachians (Fuchs et al., 2013; Klug et al., 2015, 2016; Clements et al., 2017), warming has been suggested to result in smaller hatchlings, faster growth, and maturity at smaller size (Pecl and Jackson, 2008; Hoving et al., 2013). Therefore, it is tempting to attribute this rostrum size reduction to the Early Toarcian palaeoenvironmental perturbations, since the studied samples are placed before and after the Toarcian Oceanic Anoxic Event, which falls in the Harpoceras falciferum Zone. The palaeoenvironmental perturbations, which have been attributed to the KarooFerrar igneous province activity (Pálfy and Smith, 2000), include rapid warming (Kemp et al., 2005; Gómez and Goy, 2011; Dera and Donnadieu, 2012), widespread anoxia (Pálfy and Smith, 2000; Aberhan and Baumiller, 2003), and ocean acidification (Trecalli et al., 2012). However, considering the limited scope of the present study (e.g. lack of samples in the Hildoceras bifrons Zone), an attribution to temperaturerelated stressors would be premature.

Additional analyses with higher stratigraphic coverage are still necessary in order to reconstruct belemnite's size patterns across the Upper Pliensbachian-Middle Toarcian and discard the potential overprint of background changes in environmental parameters, facies, or taphonomic factors. However, quantifying post-phragmocone size distributions in larger samples of additional belemnite accumulations might be a robust way forward.

\section{Conclusions}

Our study of two belemnite battlefields from Germany, as well as the analysis of the current literature data, exhibits a difference in rostrum size of belemnites from the Dactylioceras tenuicostatum Zone to the Haugia variabilis Zone, indicated by several size proxies. This can be observed at the community level of organization, in the whole assemblage, but also in at least one individual lineage (PassaloteuthisAcrocoelites). A rostrum size decrease was observed even when the different ontogenetic stages were individualized. It was also demonstrated that diameter-based measurements or total rostrum length are not reliable size proxies and, therefore, the apical length or three-dimensional approximations, such as the geometric mean or empirical estimates of postphragmocone volume, are more advisable. This is particularly important when comparing specimens with markedly different rostrum shapes. However, the acquisition of additional highly resolved data is necessary to disentangle potential rostrum size patterns within the Toarcian. 
Data availability. The data acquired for this analysis are available in the Supplement, together with measurements collected from the literature (Schlegelmilch, 1998).

Sample availability. The studied specimens are stored in the Bavarian Natural History Collections (Staatliche Naturwissenschaftliche Sammlungen Bayerns, SNSB). The respective reference numbers are provided in Table S2. The full-resolution image stacks (in TIFF format) and final 3-D models (in STL format) of the scanned belemnites are stored in the MorphoSource online database (www.morphosource.org; Rita, 2018), in accordance with Davies et al. (2017) specifications. They will be made public in late 2019, with the reference numbers indicated in Table S2. Additional metadata can be found in the main body of text and also in Table S1.

\section{The Supplement related to this article is available online at https://doi.org/10.5194/fr-21-171-2018-supplement.}

Author contributions. PR and KB collected field data and did the taxonomic work. Measurements and micro-CT scans were made by $\mathrm{PR}$ and MS. KB and PR wrote the paper and performed the analyses and the further interpretation. MS contributed to the project in the framework of her bachelor thesis.

Competing interests. The authors declare that they have no conflict of interest.

Acknowledgements. We would like to thank Chris Kallina, Paulina Nätscher, Kilian Eichenseer, Manya Hethke, Johann Schobert, and Birgit Leipner-Mata for help in the field, and Benjamin Gügel and Christian Schulbert for help with scanning the specimens. We thank Vanessa Roden for the English grammar and spelling revision.

This contribution was supported by the German Research Foundation (DFG; grant number Ba 5148/1-1 to KDB). This is a contribution to the DFG Research Unit FOR 2332 "TemperatureRelated Stresses as a Unifying Principle in Ancient Extinctions" (TERSANE) and to the IGCP 655 (IUGS-UNESCO). We acknowledge support by the Deutsche Forschungsgemeinschaft and Friedrich-Alexander-Universität Erlangen-Nürnberg within the funding programme Open Access Publishing.

Edited by: Rene Hoffmann

Reviewed by: Guillaume Dera and Kevin Stevens

\section{References}

Aberhan, M. and Baumiller, T. K.: Selective extinction among Early Jurassic bivalves: A consequence of anoxia, Geology, 31, 10771080, https://doi.org/10.1130/g19938.1, 2003.
Arkhipkin, A., Weis, R., Mariotti, N., and Shcherbich, Z.: 'Tailed' cephalopods, J. Mollus. Stud., 81, 345-355, https://doi.org/10.1093/mollus/eyu094, 2015.

Bandel, K. and Knitter, H.: Litho-und biofazielle Untersuchung eines Posidonienschieferprofils in Oberfranken, Geologische Blätter für Nordostbayern, 32, 95-129, 1983.

Bandel, K. and Spaeth, C.: Structural differences in the ontogeny of some belemnite rostra, in: Cephalopods - Present and Past, edited by: Wiedmann, J. and Kullmann, J., Schweizerbart, Stuttgart, 247-271, 1988.

Benito, M. I., Reolid, M., and Viedma, C.: On the microstructure, growth pattern and original porosity of belemnite rostra: insights from calcitic Jurassic belemnites, J. Iber. Geol., 42, 201-226, 2016.

Borths, M. R. and Ausich, W. I.: Ordovician-Silurian Lilliput crinoids during the end-Ordovician biotic crisis, Swiss Journal of Palaeontology, 130, 7-18, https://doi.org/10.1007/s13358-0100003-2, 2010.

Brayard, A., Nützel, A., Stephen, D. A., Bylund, K. G., Jenks, J., and Bucher, H.: Gastropod evidence against the Early Triassic Lilliput effect, Geology, 38, 147-150, https://doi.org/10.1130/g30553.1, 2010.

Caruthers, A. H., Smith, P. L., and Gröcke, D. R.: The Pliensbachian-Toarcian (Early Jurassic) extinction, a global multi-phased event, Palaeogeogr. Palaeocl., 386, 104-118, https://doi.org/10.1016/j.palaeo.2013.05.010, 2013.

Caswell, B. A. and Coe, A. L.: The impact of anoxia on pelagic macrofauna during the Toarcian Oceanic Anoxic Event (Early Jurassic), P. Geologist. Assoc., 125, 383-391, https://doi.org/10.1016/j.pgeola.2014.06.001, 2014.

Christensen, W.: Gradualistic evolution in Belemnitella from the middle Campanian of Lower Saxony, NW Germany, Bull. Geol. Soc. Den., 47, 135-163, 2000.

Clements, T., Colleary, C., De Baets, K., and Vinther, J.: Buoyancy mechanisms limit preservation of coleoid cephalopod soft tissues in Mesozoic Lagerstätten, Palaeontology, 60, 1-14, https://doi.org/10.1111/pala.12267, 2017.

Danise, S., Twitchett, R. J., Little, C. T. S., and Clémence, M.-E.: The Impact of Global Warming and Anoxia on Marine Benthic Community Dynamics: an Example from the Toarcian (Early Jurassic), PLoS ONE, 8, e56255, https://doi.org/10.1371/journal.pone.0056255, 2013.

Daufresne, M., Lengfellner, K., and Sommer, U.: Global warming benefits the small in aquatic ecosystems, P. Natl. Acad. Sci. USA, 106, 12788-12793, https://doi.org/10.1073_pnas.0902080106, 2009.

De Baets, K., Klug, C., and Monnet, C.: Intraspecific variability through ontogeny in early ammonoids, Paleobiology, 39, 75-94, https://doi.org/10.1666/0094-8373-39.1.75, 2013.

De Baets, K., Bert, D., Hoffmann, R., Monnet, C., Yacobucci, M. M., and Klug, C.: Ammonoid intraspecific variability, in: Ammonoid Paleobiology: From anatomy to ecology, Topics in Geobiology 43, edited by: Klug, C., Korn, D., De Baets, K., Kruta, I., and Mapes, R. H., Springer, Dordrecht, 359-426, 2015.

Dera, G. and Donnadieu, Y.: Modeling evidences for global warming, Arctic seawater freshening, and sluggish oceanic circulation during the Early Toarcian anoxic event, Paleoceanography, 27, PA2211, https://doi.org/10.1029/2012PA002283, 2012. 
Dera, G., Neige, P., Dommergues, J.-L., Fara, E., Laffont, R., and Pellenard, P.: High-resolution dynamics of Early Jurassic marine extinctions: the case of PliensbachianToarcian ammonites (Cephalopoda), J. Geol. Soc., 167, 21-33, https://doi.org/10.1144/0016-76492009-068, 2010.

Dera, G., Toumoulin, A., and De Baets, K.: Diversity and morphological evolution of Jurassic belemnites from South Germany, Palaeogeogr. Palaeocl., 457, 80-97, https://doi.org/10.1016/j.palaeo.2016.05.029, 2016.

Dommergues, J. L., Montuire, S., and Neige, P.: Size Patterns through Time: The Case of the Early Jurassic Ammonite Radiation, Paleobiology, 28, 423-434, 2002

Doyle, P.: The British Toarcian (Lower Jurassic) belemnites, Monogr. Palaeontogr. Soc., 144, 1-49, 1990.

Doyle, P.: Aspects of the distribution of Early Jurassic belemnites, Palaeopelagos, Special Publication, 1, 109-120, 1994.

Doyle, P. and Macdonald, D. I. M.: Belemnite battlefields, Lethaia, 26, 65-80, https://doi.org/10.1111/j.1502-3931.1993.tb01513.x, 1993.

Fuchs, D., Iba, Y., Ifrim, C., Nishimura, T., Kennedy, W. J., Keupp, H., Stinnesbeck, W., and Tanabe, K.: Longibelus gen. nov., a new Cretaceous coleoid genus linking Belemnoidea and early Decabrachia, Palaeontology, 56, 1081-1106, https://doi.org/10.1111/pala.12036, 2013.

Fuchs, D., Iba, Y., Tischlinger, H., Keupp, H., and Klug, C.: The locomotion system of Mesozoic Coleoidea (Cephalopoda) and its phylogenetic significance, Lethaia, 49, 433-454, https://doi.org/10.1111/let.12155, 2015.

Gardner, J. L, Peters, A., Kearney, M. R., Joseph. L., and Heinsohn, R.: Declining body size: a third universal response to warming?, Trends Ecol. Evol., 26, 285-291, https://doi.org/10.1016/j.tree.2011.03.005, 2011.

Gómez, J. J. and Goy, A.: Warming-driven mass extinction in the Early Toarcian (Early Jurassic) of northern and central Spain. Correlation with other time-equivalent European sections, Palaeogeogr. Palaeocl., 306, 176-195, https://doi.org/10.1016/j.palaeo.2011.04.018, 2011.

Harries, P. J. and Knorr, P. O.: What does the "Lilliput Effect" mean?, Palaeogeogr. Palaeocl., 284, 4-10, https://doi.org/10.1016/j.palaeo.2009.08.021, 2009.

Harries, P. J. and Little, C. T. S.: The early Toarcian (Early Jurassic) and the Cenomanian-Turonian (Late Cretaceous) mass extinctions: similarities and contrasts, Palaeogeogr. Palaeocl., 154, 39-66, https://doi.org/10.1016/S0031-0182(99)00086-3, 1999.

Hesselbo, S. P., Grocke, D. R., Jenkyns, H. C., Bjerrum, C. J., Farrimond, P., Morgans Bell, H. S., and Green, O. R.: Massive dissociation of gas hydrate during a Jurassic oceanic anoxic event, Nature, 406, 392-395, 2000.

Hoffmann, R., Keupp, H., and Gradl, H.: Zur Korrelation der Lias-Tongruben von Unterstürmig und Buttenheim (Frankenalb), Jahresberichte und Mitteilungen des Oberrheinischen Geologischen Vereins, 89, 37-48, 2007.

Hoffmann, R., Richter, D. K., Neuser, R. D., Jöns, N., Linzmeier, B. J., Lemanis, R. E., Fusseis, F., Xiao, X., and Immenhauser, A.: Evidence for a composite organic-inorganic fabric of belemnite rostra: Implications for palaeoceanography and palaeoecology, Sediment. Geol., 341, 203-215, https://doi.org/10.1016/j.sedgeo.2016.06.001, 2016.
Hoving, H.-J. T., Gilly, W. F., Markaida, U., Benoit-Bird, K. J., Brown, Z. W., Daniel, P., Field, J. C., Parassenti, L., Liu, B., and Campos, B.: Extreme plasticity in life-history strategy allows a migratory predator (jumbo squid) to cope with a changing climate, Glob. Change Biol., 19, 2089-2103, https://doi.org/10.1111/gcb.12198, 2013.

Hudson, R. S. and Gregoriou, A.: Calculating and comparing security returns is harder than you think: A comparison between logarithmic and simple returns, Int. Rev. Financ. Anal., 38, 151162, https://doi.org/10.1016/j.irfa.2014.10.008, 2015.

Jablonski, D.: Body size and macroevolution, in: Evolutionary paleobiology, edited by: Jablonski, D., Erwin, D. H., and Lipps, J. H., University of Chicago Press, Chicago, 256-289, 1996.

Kallina, C.: Taphonomy and carbon isotope stratigraphy of Toarcian black shales at Teufelsgraben, SE Germany, Bachelor, Naturwissenschaftliche Fakultät, Friedrich-AlexanderUniversität Erlangen-Nürnberg, 37 pp., 2016.

Kemp, D. B., Coe, A. L., Cohen, A. S., and Schwark, L.: Astronomical pacing of methane release in the Early Jurassic period, Nature, 437, 396-399, https://doi.org/10.1038/nature04037, 2005.

Keupp, H. and Schweigert, G.: Juraphyllites mimatensis (d'ORBIGNY, 1845) (Ammonoidea, Phylloceratida), a Tethyan immigrant in the Upper Pleinsbachian of Franconis (Jurassic, Southern Germany), Palaeodiversity, 1, 133-140, 2008.

Klug, C., Schweigert, G., Fuchs, D., and Dietl, G.: First record of a belemnite preserved with beaks, arms and ink sac from the Nusplingen Lithographic Limestone (Kimmeridgian, SW Germany), Lethaia, 43, 445-456, https://doi.org/10.1111/j.15023931.2009.00203.x, 2010.

Klug, C., Fuchs, D., Schweigert, G., Röper, M., and Tischlinger, H.: New anatomical information on arms and fins from exceptionally preserved Plesioteuthis (Coleoidea) from the Late Jurassic of Germany, Swiss Journal of Palaeontology, 134, 245-255, https://doi.org/10.1007/s13358-015-0093-y, 2015.

Klug, C., Schweigert, G., Fuchs, D., Kruta, I., and Tischlinger, H.: Adaptations to squid-style high-speed swimming in Jurassic belemnitids, Biol. Lett., 12, 20150877, https://doi.org/10.1098/rsbl.2015.0877, 2016.

Kolmogorov, A.: Sulla determinazione empirica di una lgge di distribuzione, Giornale dell' Istituto Italiano degli Attuari, 4, 83-91, 1933.

Kosnik, M. A., Jablonski, D., Lockwood, R., and NovackGottshall, P. M.: Quantifying molluscan body size in evolutionary and ecological analyses: Maximizing the return on data collection efforts, Palaios, 21, 588-597, https://doi.org/10.2110/palo.2006.p06-012r, 2006.

Little, C. T. S. and Benton, M. J.: Early Jurassic mass extinction: A global long-term event, Geology, 23, 495-498, https://doi.org/10.1130/00917613(1995)023<0495:ejmeag>2.3.co;2, 1995.

Mancini, E. A.: Origin of Micromorph Faunas in the Geologic Record, J. Paleontol., 52, 311-322, https://doi.org/10.2307/1303707, 1978.

Mann, H. B. and Whitney, D. R.: On a Test of Whether one of Two Random Variables is Stochastically Larger than the Other, Ann. Math. Stat., 18, 50-60, 1947.

Martindale, R. C. and Aberhan, M.: Response of macrobenthic communities to the Toarcian Oceanic Anoxic Event in northeastern Panthalassa (Ya Ha Tinda, Al- 
berta, Canada), Palaeogeogr. Palaeocl., 478, 103-120, https://doi.org/10.1016/j.palaeo.2017.01.009, 2017.

McGowan, A., Smith, A., and Taylor, P.: Faunal diversity, heterogeneity and body size in the Early Triassic: testing postextinction paradigms in the Virgin Limestone of Utah, USA, Aust. J. Earth Sci., 56, 859-872, 2009.

Monks, N., Hardwick, J. D., and Gale, A.: The Function of the Belemnite Guard, Palaeontol. Z., 70, 425-431, https://doi.org/10.1007/BF02988082, 1996.

Mood, A. M.: On the Joint Distribution of the Medians in Samples from a Multivariate Population, Ann. Math. Stat., 12, 268-278, 1941.

Mood, A. M.: On the Asymptotic Efficiency of Certain Nonparametric Two-Sample Tests, Ann. Math. Stat., 25, 514-522, 1954.

Morten, S. D. and Twitchett, R. J.: Fluctuations in the body size of marine invertebrates through the PliensbachianToarcian extinction event, Palaeogeogr. Palaeocl., 284, 29-38, https://doi.org/10.1016/j.palaeo.2009.08.023, 2009.

Nixon, M. and Young, J. Z.: The brains and lives of cephalopods, Oxford University Press, Oxford, 2003.

Novack-Gottshall, P. M.: Using Simple Body-Size Metrics to Estimate Fossil Body Volume: Empirical Validation Using Diverse Paleozoic Invertebrates, Palaios, 23, 163-173, https://doi.org/10.2110/palo.2007.p07-017r, 2008.

Nürnberg, S., Aberhan, M., and Krause, R. A.: Evolutionary and ecological patterns in body size, shape, and ornamentation in the Jurassic bivalve Chlamys (Chlamys) textoria (Schlotheim, 1820), Foss. Rec., 15, 27-39, https://doi.org/10.1002/mmng.201200002, 2012.

Ohlberger, J.: Climate warming and ectotherm body size - from individual physiology to community ecology, Funct. Ecol., 27, 991-1001, https://doi.org/10.1111/1365-2435.12098, 2013.

Pálfy, J., and Smith, P. L.: Synchrony between Early Jurassic extinction, oceanic anoxic event, and the Karoo-Ferrar flood basalt volcanism, Geology, 28, 747-750, https://doi.org/10.1130/00917613(2000)28<747:sbejeo>2.0.co;2, 2000.

Pecl, G. and Jackson, G.: The potential impacts of climate change on inshore squid: biology, ecology and fisheries, Rev. Fish Biol. Fisher., 18, 373-385, https://doi.org/10.1007/s11160-007-90773, 2008.

Pinard, J. D., Weis, R., Neige, P., Mariotti, N., and Di Cencio, A.: Belemnites from the Upper Pliensbachian and the Toarcian (Lower Jurassic) of Tournadous (Causses, France), N. Jb. Geol. Paläont. Abh., 273/2, 155-177, https://doi.org/10.1127/00777749/2014/0421, 2014.

R Core Team, R: A language and environment for statistical computing, R Foundation for Statistical Computing, Vienna, Austria, https://www.R-project.org/ (last access: August 2017), 2018.

Rego, B. L., Wang, S. C., Altiner, D., and Payne, J. L.: Within- and among-genus components of size evolution during mass extinction, recovery, and background intervals: a case study of Late Permian through Late Triassic foraminifera, Paleobiology, 38, 627-643, https://doi.org/10.1666/11040.1, 2012.

Reitner, J. and Urlichs, M.: EchteWeichteilbelemniten aus dem Untertoarcium (Posidonienschiefer) Südwestdeutschlands, N. Jb. Geol. Palaeont. Abh., 165, 450-465, 1983.

Riegraf, W.: Revision der Belemniten des Schwäbischen Jura, Teil 7, Palaeontographica Abteilung A, 128-206, 1980.
Rita, P.: Rostrum size differences between Toarcian belemnite battlefields, available at: www.morphosource.org, last access: March 2018.

Rodríguez-Tovar, F. J., Miguez-Salas, O., and Duarte, L. V.: Toarcian Oceanic Anoxic Event induced unusual behaviour and palaeobiological changes in Thalassinoides tracemakers, Palaeogeogr. Palaeocl., 485, 46-56, https://doi.org/10.1016/j.palaeo.2017.06.002, 2017.

Roper, C. F. and Voss, G. L.: Guidelines for taxonomic descriptions of cephalopod species, Mem. Natl. Mus. Vic., 44, 48-63, 1983.

Sanders, M., Bardin, J., Benzaggagh, M., and Cecca, F.: Early Toarcian (Jurassic) belemnites from northeastern Gondwana (South Riffian ridges, Morocco), Palaeontol. Z., 89, 51-62, https://doi.org/10.1007/s12542-013-0214-0, 2015.

Schlegelmilch, R.: Die Belemniten des süddeutschen Jura, Gustav Fischer, Stuttgart, 151 pp., 1998.

Seilacher, A.: Swimming habits of belemnites - recorded by boring barnacles, Palaeogeogr. Palaeocl., 4, 279-285, 1968.

Smirnov, N.: Table for Estimating the Goodness of Fit of Empirical Distributions, Ann. Math. Stat., 19, 279-281, https://doi.org/10.1214/aoms/1177730256, 1948.

Sogot, C. E., Harper, E. M., and Taylor, P. D.: The Lilliput Effect in Colonial Organisms: Cheilostome Bryozoans at the Cretaceous-Paleogene Mass Extinction, PLoS ONE, 9, e87048, https://doi.org/10.1371/journal.pone.0087048, 2014.

Spaeth, C.: Zur Frage der Schwimmverhältnisse bei Belemniten in Abhängigkeit vom Primärgefüge der Hartteile, Palaeontol. Z., 49, 321-331, https://doi.org/10.1007/bf02987666, 1975.

Stevens, K., Griesshaber, E., Schmahl, W., Casella, L. A., Iba, Y., and Mutterlose, J.: Belemnite biomineralization, development, and geochemistry: The complex rostrum of Neohibolites minimus, Palaeogeogr. Palaeocl., 468, 388-402, https://doi.org/10.1016/j.palaeo.2016.12.022, 2017.

Trecalli, A., Spangenberg, J., Adatte, T., Föllmi, K. B., and Parente, M.: Carbonate platform evidence of ocean acidification at the onset of the early Toarcian oceanic anoxic event, Earth Planet. Sc. Lett., 357-358, 214-225, https://doi.org/10.1016/j.eps1.2012.09.043, 2012.

Twitchett, R. J.: The Lilliput effect in the aftermath of the endPermian extinction event, Palaeogeogr. Palaeocl., 252, 132-144, https://doi.org/10.1016/j.palaeo.2006.11.038, 2007.

Ullmann, C. V., Thibault, N., Ruhl, M., Hesselbo, S. P., and Korte, C.: Effect of a Jurassic oceanic anoxic event on belemnite ecology and evolution, P. Natl. Acad. Sci. USA, 111, 10073-10076, https://doi.org/10.1073/pnas.1320156111, 2014.

Urlichs, M.: Alter und Genese des Belemnitenschlachtfeldes im Toarcien von Franken, Geologische Blätter NO-Bayern, 21, 6583, 1971.

Weis, R., Neige, P., Dugué, O., Di Cencio, A., Thuy, B., Numberger-Thuy, L., and Mariotti, N.: Lower Jurassic (Pliensbachian-Toarcian) belemnites from Fresneyle-Puceux (Calvados, France): taxonomy, chronostratigraphy and diversity, Geodiversitas, 40, 87-113, https://doi.org/10.5252/geodiversitas2018v40a4, 2018.

Wignall, P. B., Newton, R. J., and Little, C. T. S.: The timing of paleoenvironmental change and cause-and-effect relationships during the early Jurassic mass extinction in Europe, Am. J. Sci., 305, 1014-1032, https://doi.org/10.2475/ajs.305.10.1014, 2005. 